УДК 373.016.091-057.87:744:004

DOI:

Іван Нищак, доктор педагогічних наук, дочент, професор кафедри технологічної та професійної освіти Дрогобииького державного педагогічного університету імені Івана Франка Тетяна Гавриш, студентка Дрогобицького державного педагогічного університету імені Івана Франка

Андрій Улич, аспірант кафедри технологічної та професійної освіти Дрогобицького державного педагогічного університету імені Івана Франка

\title{
РОЗВИТОК ПРОСТОРОВОГО МИСЛЕННЯ УЧНІВ НА УРОКАХ КРЕСЛЕННЯ ЗАСОБАМИ ЦИФРОВИХ ТЕХНОЛОГІЙ
}

У статті досліджено иляхи і засоби иілеспрямованого розвитку просторового мислення учнів в умовах комп 'ютерно-орієнтованого навчання креслення. Досліджено сутність та значення просторового мислення для всебічного розвитку особистості. 3'ясовано можливості изифрових технологій (ЦТ) як засобу розвитку просторового мислення учнів на уроках креслення. Встановлено, щчо найбільш доцільним для розвитку просторового мислення учнів є використання комп'ютерних програмних засобів імітаційно-моделюючого muny.

Ключові слова: графічна підготовка; креслення; програмний засіб; просторове мислення; ичифрові технології.

תim. 7.

Ivan Nyshchak, Doctor of Sciences (Pedagogy), Associate Professor, Professor of the Technological and Vocational Education Department Drohobych Ivan Franko State Pedagogical University

Tetyana Havrysh, Student of Drohobych Ivan Franko State Pedagogical University Andriy Ulych, Postgraduate Student of the Technological and Vocational Education Department Drohobych Ivan Franko State Pedagogical University

\section{DEVELOPMENT OF STUDENT SPATIAL THINKING IN DRAWING LESSONS BY DIGITAL TECHNOLOGIES}

The article explores the ways and means of the purposeful development of students' spatial thinking in the conditions of computer-oriented drawing lessons. It is established that the essence of spatial thinking is the mental formation of spatial images and their manipulation in solving the educational and industrial problems. Spatial thinking represents and functions in a complex unity of different mental processes: perception, memory, imagination, etc. The basic operational units of spatial thinking are spatial images that reflect not all the properties and characteristics of the objective world, but only spatial ones. The content of these images is the result of reproduction and transformation of spatial features and relationships of objects (shape, size, location of structural elements, etc.). The possibilities of digital technologies as a means of developing the students' spatial thinking in drawing lessons are clarified. The use of digital technologies, including special computer programs, provides ample opportunities for visual presentation of educational information from the school drawing course. They can be used to display different types of educational information (figurative, graphic) in close connection with the symbolic, which allows you to use the latest visualization methods in the learning process, including modeling. It is established that the most expedient for the development of students' spatial thinking is the use of computer software of simulation type, which allows to carry out design and graphic activities of students, providing further opportunities for computer computational experiments. Such software tools provide a higher level of clarity - dynamic clarity. Working with modeling and simulation of computer programs, the student has the opportunity to comprehensively study geometric objects, identify their significant and insignificant features, observe and analyze the results of their actions, draw conclusions based on their own observations.

Keywords: graphic training; painting; software; spatial thinking; digital technologies.

П остановка наукової проблеми та її значення. Сприйняття школярами навколишнього тривимірного світу, предметів, що його складають, а також успішне розв'язання різнотипних просторових завдань потребує наявності стійких просторових образів, що складають підгрунтя просторового мислення. Саме тому низький рівень розвитку просторового мислення перешкоджає належному опануванню учнями таких навчальних дисциплін, як геометрія та креслення, оскільки маніпулювання просторовими об'єктами у процесі вивчення цих 
шкільних предметів $є$ особливим видом навчально-пізнавальної діяльності учнів [5].

Необхідність формування просторового мислення особистості зумовлює цілеспрямований пошук нових ідей щодо якісного поліпшення змісту, організаційних форм, дидактичних методів і відповідних засобів реалізації освітнього процесу, позаяк від цього залежить не лише очікуваний результат, але й загальний рівень мисленнєвого розвитку учнів.

Використання у навчанні засобів цифрових технологій, зокрема комп'ютерної техніки 3 відповідним програмним забезпеченням, дає змогу застосовувати найрізноманітніші методи навчання, у тому числі й ті, що в умовах традиційних форм навчальної діяльності використовуються зі значними обмеженнями.

Виважене, розумне впровадження в педагогічну практику цифрових технологій забезпечує перехід від репродуктивного характеру навчання і механічного засвоєння знань учнями до надання навчальній діяльності дослідницького спрямування. Це значно підвищує пізнавальну самостійність учнів, сприяє розвиткові мисленнєвих процесів особистості, зокрема просторового мислення.

Аналіз досліджень 3 проблеми. Актуальні питання розвитку просторового мислення особистості, зокрема в процесі навчальнопізнавальної діяльності, розкриваються у наукових працях багатьох відомих вітчизняних та зарубіжних вчених: А. Брушлинського, С. КабановоїМеллєр, А. Корнєєвої, С. Максименка, О. Тіхомірова, I. Якиманської та ін. Дослідженням різних аспектів організації комп’ютерно-орієнтованого навчання в закладах освіти займалися В. Биков, М. Жалдак, Б. Малиновський, Ю. Машбиць, Ю. Рамський, I. Ретинська та ін. Дидактичні можливості цифрових технологій у процесі трудової та графічної підготовки школярів всебічно висвітлювалися О. Ващук, Р. Гуревичем, В. Стешенком, I. Петрициним, М. Юсуповою та ін.

Мета статті - дослідити шляхи і засоби цілеспрямованого розвитку просторового мислення учнів в умовах комп'ютерноорієнтованого навчання креслення.

Виклад основного матеріалу. Специфіка мислення зумовлюється характером завдань, які розв'язує індивід. Через те з'являються особливі для певного виду мислення взаємопоєднання наочності і вербальності, чуттєвого й мисленнєвого, інтелектуальних та практикоорієнтованих дій. Томуза характером об'єкта інтелектуальної діяльності особистості у психології прийнято виокремлювати наочно-дійове, образне та понятійне мислення [2].
Наочно-дійовим мисленням називають такі прояви мислення, які актуалізуються у ситуації сприймання конкретних об'єктів й оперування ними. Водночас зміст образного мислення складають переважно образи, тобто більше чи менше узагальнені уявлення про його об'єкти. При цьому розрізняють наочно-образне та репродуктивно-образне мислення. Якщо людина має справу 3 предметами або їх зображеннями, але оперує ними лише у свідомості, спираючись на їхнє просторове відображення, то домінує наочно-образне мислення. Коли оперування образами у свідомості відбувається без живого сприйняття об'єктів, то має місце репродуктивно-образне мислення. Понятійним називають мислення, що характеризується домінуванням понятійного змісту над просторовим. Залежно від того, які поняття при цьому переважають, розрізняють конкретно-понятійне й абстрактно-понятійне мислення [2].

Зважаючи на окреслену мету наукового дослідження, потребує уточнення зміст дефініції “просторове мислення” та виявлення його значення для всебічного розвитку особистості учнів.

Просторове мислення розвивається головно на наочному матеріалі й оперує візуальними образами, тому окремі дослідники ([2]; [6]; [7] та ін.) відносять його до різновиду так званого образного (візуального), яке проявляється у процесі оперування зоровими образами.

Образне мислення, на думку І. Якиманської, - складний процес перетворення чуттєвої інформації, який забезпечується перцептивними діями, що уможливлюють створення образів відповідно до “вихідного матеріалу”, оперування цими образами, розв’язок задач на порівняння образів, їх виокремлення, модифікацію 3 врахуванням специфіки суб'єктивного досвіду [7].

Просторове мислення завжди оперує наочністю. При цьому образи постають первинним продуктом, найменшою оперативною складовою, а також результатом мисленнєвого процесу. Словесне відображення у просторовому мисленні використовується лише для опису, пояснення зафіксованих наочних (образних) трансформацій.

Таким чином, сутність просторового мислення полягає у мисленнєвому формуванні просторових образів (при изьому че зазвичай здійснюється $з$ використанням різного наочного підгрунтя) і маніпулюванні ними при розв'язанні навчальних та виробничотехнічних задач. 


\section{РОЗВИТОК ПРОСТОРОВОГО МИСЛЕННЯ УЧНІВ НА УРОКАХ КРЕСЛЕННЯ ЗАСОБАМИЦИФРОВИХ ТЕХНОЛОГЙ}

Психологічним механізмом просторового мислення є діяльність уяви, що уможливлює створення просторових образів, оперування ними, перекодування їх у заданому (або довільно вибраному) напрямі, використання різних систем відліку для побудови образів, виділення в образі різних ознак і властивостей об'єктів, важливих для конкретного індивіда [6].

Основними оперативними одиницямипросторового мислення єпросторові (геометричні) образи, в яких відображаються не всі властивості й ознаки предметного світу, а лише просторові. Змістом цих образів $\epsilon$ результат відтворення i трансформації просторових ознак та відношень об'єктів (форми, розмірів, розташування конструктивних елементів тощо). Саме через це просторове мислення вирізняється з-поміж інших видів мисленнєвої діяльності індивіда, у яких процес виокремлення просторово-образних властивостей предметів не є ключовим.

Просторовий образ об'єкта формується під впливом двох взаємопов'язаних чинників: наочної основи та вимог дійсності, обумовленими конкретними умовами задачі. Цю закономірність необхідно враховувати при використанні дидактичного принципу наочності з метою створення сприятливого навчального середовища для ефективного розвитку просторового мислення учнів. Просторові образи, якими оперує мислення, мають бути динамічними, рухливими, оперативними. Образи є важливою основою чуттєвого абстрагування та узагальнення [7].

Просторове мислення - невід'ємний компонент творчої діяльності людини, оскільки звільняє ії від необхідності постійного застосування розгорнутої структури словесних умовиводів. Наявність у мисленні просторово-образної компоненти $€$ необхідною умовою лаконічності внутрішньої мови. Образ виступає не лише як кінцевий продукт діяльності, але і як певний показник пізнавального рівня та регулятор мисленнєвої діяльності особистості.

Ефективна робота просторового мислення учнів у процесі навчально-пізнавальної діяльності виступає однією з умов, що забезпечує засвоєння навчального матеріалу (зокрема з креслення) на належному рівні. Навчання приводить до розвитку мислення школярів, якщо воно правильно організоване, враховує закономірності психічного розвитку особистості, здійснюється на основі активної пізнавальної діяльності учнів. Тому виникає необхідність розробки таких прийомів роботи, які вимагали б від учнів самостійності мислення, мобілізували їхні зусилля при розв'язуванні пізнавальних задач, залучали до активного пошуку.
Успішне розв'язання актуальних питань, пов'язаних із розвитком просторового мислення школярів, можливе завдяки цілеспрямованому й дидактично обгрунтованому використанню сучасних засобів цифрових технологій навчання, які здатні внести суттєві зміни до усіх компонентів освітнього процесу (мету, зміст, методи, організаційні форми, роль вчителя).

Цифрові технології навчання - система сучасних інформаційних методів і засобів створення, збирання, зберігання, опрацювання, подання й використання даних і знань у навчанні, а також сукупність наукових знань про іï функціонування, спрямована на удосконалення навчального процесу 3 найменшими затратами [1].

Цілеспрямоване залучення ЦТ забезпечує широкі можливості для наочного представлення навчальних відомостей шкільного курсу креслення. 3 їх допомогою можна забезпечити відображення різних видів навчальної інформації (образної, графічної) у тісному зв'язку із знаковосимвольною, яка притаманна математиці, що дає змогу використовувати в освітньому процесі новітні способи унаочнення, зокрема моделювання.

Моделювання постає важливим методом пізнання, формою відображення дійсності, що полягає у з'ясуванні чи відтворенні певних властивостей реальних об'єктів (предметів, явищ, процесів) за допомогою інших об'єктів, або їх абстрактного опису у вигляді зображення, плану, карти, сукупності рівнянь, алгоритмів, програм тощо.

Використання ЦТ на уроках креслення 3 метою моделювання об'єктів навчальної діяльності учнів уможливлює представлення наочного образу графічного поняття, підкріплюючи його відповідною числовою інформацією.

Здатність до візуалізації абстрактних математичних понять (під візуалізацією розуміється сукупність різних перетворень наочного матеріалу (динамічних моделей), що призводить до формування цілісного образу) перетворює ЦТ на ефективний і потужний засіб при вивченні більшості навчальних тем шкільного курсу креслення, зокрема породжує у школярів бажання висувати оригінальні гіпотези та здійснювати пошук нестандартних шляхів розв'язування графічних задач, сприяє розвиткові творчих і евристичних складових мислення, підвищує результативність засвоєнню нових знань.

Серед різних видів ЦТ найбільшого поширення на уроках креслення набули педагогічні програмні 


\section{РОЗВИТОК ПРОСТОРОВОГО МИСЛЕННЯ УЧНІВ НА УРОКАХ КРЕСЛЕННЯ ЗАСОБАМИЦИФРОВИХ ТЕХНОЛОГІЙ}

засоби (ППЗ), орієнтовані на удосконалення навчального процесу, розвиток пізнавальної самостійності учнів, формування практичних умінь і навичок, активізацію мисленнєвих процесі особистості та ін.

Нині на ринку програмного забезпечення існує велика кількість педагогічних програмних засобів, які, залежно від призначення, прийнято умовно поділяти на [4]:

1) програми, орієнтовані на самостійну роботу учнів 3 цифровою технікою (тренувальні, настановчі, програми для організації проблемного навчання, імітаційні і моделюючі програмні засоби, ігрові програми та ін.);

2) програми для комп'ютерної підтримки роботи вчителя (контролюючі ППЗ з функціями статистичного аналізу даних, діагностичні і демонстраційні (ілюстративні) програми та ін.).

Необхідно зазначити, що більшість 3 наявних програмних засобів можна віднести одразу до кількох окреслених типів ППЗ. Так, часто настановчі програми оснащені функціями контролю (ANALIT та ін.), ігрові програми реалізують деякі тренувальні функції (MathManiac, Adventure Math та ін.), окремі імітаційні і моделюючі програмні засоби можуть використовуватися як демонстраційні (Cabri, DG, Geometer's Sketchpad, $G R A N-2 D, G R A N-3 D$ та ін.).

Аналіз результатів психолого-педагогічних досліджень І. Якиманської [7] та В. Моляка [3] доводить, що розвиток просторового мислення учнів найбільш ефективно здійснюється у процесі їх конструкторсько-графічної діяльності. Тому можна припустити, що найбільш доцільними для розвитку просторового мислення учнів $\epsilon$ ті програмні засоби, використання яких уможливлює реалізацію елементів конструкторсько-графічної діяльності школярів, додатково забезпечуючи можливість для проведення комп'ютерних обчислювальних експериментів. Таким вимогам відповідає лише один тип програмних засобів імітаційно-моделюючі, в яких як основний засіб навчання використовується імітація та педагогічне моделювання.

Основна перевага комп'ютерних програм імітаційно-моделюючого типу перед демонстраційними ППЗ полягає у тому, що учень, отримуючи візуальну інформацію, може змінювати параметри віртуальних моделей, одночасно відслідковуючи зміни, які при цьому відбулися. В імітаційно-моделюючих програмних засобах забезпечується вищий рівень наочності - динамічна наочність. Тому, працюючи з такими програмами, учень має змогу всебічно досліджувати геометричні об'єкти, виділяти їх суттєві та несуттєві ознаки, спостерігати й аналізувати результати своїх дій, робити висновки на основі власних спостережень. Для прикладу, при дослідженні комп’ютерної моделі піраміди можна збільшувати або зменшувати ії висоту, чи довжину сторін основи, відслідковуючи, як ці зміни впливають на її об’ $€$ м, площу бічної поверхні тощо.

У процесі роботи 3 комп'ютерними програмними засобами імітаційно-моделюючого типу школярі мають змогу досліджувати геометричні об'єкти різного рівня складності. Завдяки цьому в учнів з'являється можливість для дослідницької, творчої діяльності, що забезпечує формування пізнавального інтересу, сприяє розумовій активності школярів.

Таким чином, можливість навчального моделювання дає змогу використовувати цифрові технології (зокрема комп'ютер з відповідним програмним забезпеченням) як принципово новий інструмент пізнання навколишньої дійсності. Процес моделювання важливий для формування в учнів повноцінних узагальнених образів досліджуваних об’єктів, що має значний вплив на розвиток їх просторового мислення.

Поширення цифрових технологій на всі сфери людської діяльності привело до появи значної кількості пакетів графічного моделювання, найвідомішими серед яких є 3 DStudio, Bryce $3 D$, AutoCAD, Cabri, Geometer's Sketchpad.

3DStudio та Bryce3D - професійні пакети тривимірної анімації і візуалізації, основу яких складають конструктор моделей, інтерпретатор мови написання сценаріїв та модуль інверсної кінематики. У цих середовищах можна створювати та змінювати моделі довільних просторових об'єктів, виконувати операції перетину та об'єднання об'єктів. Завдяки технології прорахунку ходу променів (ray-tracing) при побудові окремих сцен та можливості роботи 3 текстурами, можна легко згенерувати реалістичне зображення і анімацію створених об'єктів з врахуванням положення джерел світла та “камер”. Ці програмні продукти мають необмежені можливості для конструювання та візуалізації об'єктів, проте в них не передбачена можливість отримання числових характеристик об'єктів (об’ємів, площ, довжин сторін, величин кутів тощо). Крім цього, вказані програми досить вибагливі до апаратних ресурсів комп'ютера, а процес побудови графічних зображень створених тривимірних моделей доволі довготривалий.

Програмний засіб AutoCAD - універсальна система автоматизованого проєктування (САПР), орієнтована на фахівців-інженерів, що дає змогу моделювати реальні об'єкти і процеси 


\section{РОЗВИТОК ПРОСТОРОВОГО МИСЛЕННЯ УЧНІВ НА УРОКАХ КРЕСЛЕННЯ ЗАСОБАМИЦИФРОВИХ ТЕХНОЛОГІЙ}

різного рівня складності. За можливостями конструювання та візуалізації об'єктів AutoCAD майже не поступається пакетам 3 DStudio та Bruce $3 D$, водночас забезпечуючи можливість змінювати вихідні параметри моделей, отримувати відповідні числові характеристики та досліджувати їх властивості і залежності.

Системи автоматизованого проєктування доволі ефективні на уроках креслення з позиції їх моделюючих та обчислювальних можливостей, зокрема для розвитку просторового мислення учнів. Однак вони (САПР) орієнтовані головно на інженерів-професіоналів, мають специфічно складний інтерфейс, що утруднює їх належне опанування школярами й, відповідно, обмежує використання у навчальному процесі. Тому в графічній підготовці учнів доцільно застосовувати лише ті програмні засоби, для роботи з якими не обов'язково володіти спеціальними технічними знаннями і прийомами, інакше це призведе до нераціонального розподілу навчального часу, який використовуватиметься не на вивчення креслення, а на освоєння програмного засобу.

Висновки. Таким чином, у процесі науковопедагогічного дослідження встановлено, що серед засобів цифрових технологій найбільш ефективними для розвитку просторового мислення учнів $є$ ППЗ імітаційно-моделювального типу. Однак доводиться констатувати відсутність таких програмних засобів, головно україномовних, які можна було б успішно використовувати у процесі графічної підготовки школярів. Більшість 3 наявних ППЗ мають англомовний інтерфейс та розроблені без урахування особливостей вивчення шкільного курсу креслення. Зважаючи на це, актуалізується потреба в розробці вузькоспрямованих авторських педагогічних програмних засобів для вивчення креслення, спеціально зорієнтованих на активізацію та розвиток мисленнєвих процесів особистості, зокрема просторового мислення учнів.

\section{ЛІТЕРАТУРА}

1. Жалдак M.I. Педагогічний потенціал комп'ютерно орієнтованих систем навчання математики. Засоби $i$ технології єдиного інформаційного освітнього простору: зб. наук. праць; за ред. В.Ю. Бикова, Ю.О. Жука. Київ: Атака, 2004. С. $61-73$.

2. Кудрявцев Т.В. Психология технического мышления (Процесс и способы решения технических задач). Москва: Педагогика, 1975. $304 \mathrm{c}$.

3. Моляко В.А. Психология конструкторской деятельности. Москва: Машиностроение, 1983. $134 \mathrm{c}$.
4. Нищак І.Д. Методична система навчання інженерно-графічних дисциплін майбутніх учителів технологій: монографія. Дрогобич: РВВ ДДПУ ім. І. Франка, 2016. 264 с.

5. Нищак І.Д. Інформаційні технології як засіб розвитку технічного мислення (методика використання на заняттях 3 креслення): навч.метод. посіб. Дрогобич: РВВ ДДПУ ім. І. Франка, 2008. $108 \mathrm{c}$.

6. Тихомиров О.К. Психология мышления. Москва: Изд-во Моск. ун-та, 1984. 272 с.

7. Якиманская И.С. Индивидуальные психологические различия в оперировании пространственными отношениями у школьников. Вопросы психологии. 1976. № 3. С.69-80.

\section{REFERENCES}

1. Zhaldak, M. I. (2004). Pedahohichnyi potentsial kompiuterno oriientovanykh system navchannia matematyky [Pedagogical potential of computerbased systems in mathematics]. Means and technologies of a single information educational space: coll. Science. works; (Ed.).V. Bykov, Yu. Zhuk. Kyiv, pp. $61-73$. [in Ukrainian].

2. Kudryavtsev, T. V. (1975). Psihologiya tehnicheskogo myishleniya (Protsess i sposobyi resheniya tehnicheskih zadach) [Psychology of technical thinking (Process and ways of solving technical problems)]. Moscov, 304 p. [in Russian].

3. Molyako, V. A. (1983). Psihologiya konstruktorskoy deyatelnosti [Psychology of design activity]. Moscov, 134 p. [in Russian].

4. Nyshchak, I. D. (2016). Metodychna systema navchannia inzhenerno-hrafichnykh dystsyplin maibutnikh uchyteliv tekhnolohii [Methodical system of teaching engineering and graphic disciplines of future teachers of technology]. Drohobych, $264 \mathrm{p}$. [in Ukrainian].

5. Nyshchak, I. D. (2008). Informatsiini tekhnolohii yak zasib rozvytku tekhnichnoho myslennia (metodyka vykorystannia na zaniattiakh z kreslennia) [Information technology as a means of developing technical thinking (methods of use in drawing lessons)]. Drohobych, 108 p. [in Ukrainian].

6. Tihomirov, O. K. (1984). Psihologiya myishleniya [Psychology of thinking]. Moscov, 272 p. [in Russian].

7. Yakimanskaya, I.S. (1976). Individualnyie psihologicheskie razlichiya $\mathrm{v}$ operirovanii prostranstvennyimi otnosheniyami u shkolnikov [Individual psychological differences in the operation of spatial relationships among schoolchildren]. Psychology issues. No. 3. pp. $69-80$. [in Russian]. Стаття надійшла до редакції 21.10.2020 